\title{
Introduction: Valuing Historic Environments
}

\author{
Lisanne Gibson and John Pendlebury
}

\section{Introduction}

There is a contemporary imperative to consider different cultural, historical and social values as equal. If we accept this and take it take seriously, how do we overcome the practical issues this presents for the management as heritage of historic environments and cultural landscapes? This single question is probably the most significant issue facing contemporary heritage management and policy. It is this challenge to heritage management that this rich compilation of essays on a wide diversity of environments (physical and institutional) and landscapes aims to address. If the socially democratic context for our contemporary understanding of value is one of pluralization, involving the validation of multiple conceptions of value, what does this mean for acts of preservation which are, by their very nature, based on processes which involve the fixing of meaning and value?

All of the authors contributing to this collection proceed on the basis that concepts of cultural, historical, or social value are culturally and historically constructed. This theoretical orientation posits most crucially that value is not an intrinsic quality but rather the fabric, object or environment is the bearer of an externally imposed culturally and historically specific meaning, that attracts a value status depending on the dominant frameworks of value of the time and place. Such an orientation has consequences both for the assessment of significance and the heritage management of a building, object or environment.

That concepts of value are constructed has become the dominant theoretical approach across the humanities and social sciences. In a democratic society, it is argued, definitions of value cannot be singular but must allow for plural interpretations and meaning. In the heritage field this 'cultural turn' has led to a questioning of what constitutes value. ${ }^{1}$ This has resulted in erosion of the previously dominant notion of value which understood it as intrinsic to the object or environment and able to be revealed by the correct processes of investigation which could be conducted only by a limited body of experts.

1 See for instance, Avrami, E., et al., Values and Heritage Conservation, (Los Angeles: The Getty Conservation Institute, 2000) and De La Torre, M., Assessing the Values of Cultural Heritage, (Los Angeles: The Getty Conservation Institute, 2002). 
In part this understanding of the validity of multiple concepts of value emanates from the recognition that acts of preservation have cultural, economic, political, and social consequences. The preservation of an object or environment is an assertion of its importance and therefore the culture or history associated with it. Such artefacts or environments and the meanings they represent are often integrally tied to the identity formations of particular groups or communities. This can have both positive and negative effects. ${ }^{2}$ On the one hand, if singular understandings of value are prioritized and supported over others the consequences are the support of one group's culture and not another's. ${ }^{3}$ As Lisanne Gibson and Laurajane Smith discuss in their contributions to this book the support of particular cultural forms may have political, social and even economic effects through the support of particular systems of 'cultural capital'. On the other hand, the recognition of the connections between identities and objects or environments has also led to a multiplication of programmes, including heritage programmes, which in recognizing the validity of plural value frameworks seek to enable and empower a diversity of communities and individuals through actively supporting and valuing their stories, objects and places. ${ }^{4}$ Thus, while cultural support (funding or preservation) can be articulated to socially democratic discourses we must nevertheless remain aware that cultural support involves choices which have cultural, economic, political and social ramifications. ${ }^{5}$

The burgeoning of publicly funded cultural support, including for heritage, since the 1970s and the recognition that there are cultural, economic, political and social effects of cultural support has led to a requirement that cultural programmes must affect social and public policy outcomes, such as regeneration. ${ }^{6}$ This shift has put increasing pressure on cultural programmes to respond to (shifting) Government objectives rather than responding to logics which are defined internally to the field. ${ }^{7}$ Recently the cultural policy, museum and heritage studies literatures have

2 L. Gibson and J. Besley, Monumental Queensland: Signposts on a Cultural Landscape, (Brisbane: University of Queensland Press, 2004), 8-15, see also Gibson this volume and Smith this volume.

3 P. Bourdieu, Distinction: A Social Critique of the Judgement Of Taste, (Oxford: Routledge, 1984); T. Bennett, and E.B. Silva, 'Cultural Capital and Inequality: Policy Issues and Contexts', Cultural Trends, 15, 2/3 (2006): 87-106; and T. Bennett and M. Savage, 'Introduction: Cultural Capital and Cultural Policy', Cultural Trends 13, 2, (2004): 7-14.

4 P. Davis, Ecomuseums: A Sense of Place, (Leicester: Leicester University Press, 1999); A. Newman, F. McLean, and G. Urquhart, 'Museums and the active citizen: tackling the problems of social exclusion'. Citizenship Studies, 9, 1 (2005): 41-57.

5 L. Gibson, The Uses of Art: Constructing Australian Identities, (Brisbane: University of Queensland Press, 2001); J. Pendlebury et al., 'The Conservation of English Cultural Built Heritage: A Force for Social Inclusion?', International Journal for Heritage Studies, 10, 1 (2004): 11-32.

6 L. Gibson, The Uses of Art: Constructing Australian Identities, op. cit.; L. Gibson, 'In defence of Instrumentality', Cultural Trends, 17, 4, (2008): 247-257.

7 J. Pendlebury, Conservation and the Age of Consensus, (London: Routledge, 2009); I. Strange and D. Whitney, 'The changing roles and purposes of heritage conservation in 
contained a great deal of discussion of this so called 'instrumentalization' of cultural institutions and programmes which is described by this literature as emerging over the last thirty or so years. This perception of culture's co called 'instrumentalization' seems to be widespread and is primarily perceived as a 'threat'. ${ }^{8}$ However, in these deconstructions, primarily aimed at the poor impact studies and overblown claims made for the arts and heritage, there is little to guide us towards a way of thinking which takes seriously the practical challenges for cultural and heritage management and policy. Our purpose is querying the utility of such critiques is not to propose a simple acceptance of the status quo, far from it. Rather, it is to identify that one of the problem's with the attack on the 'instrumentalization' of culture is that it leaves the field open for a return to the kinds of elite, exclusionary policies which have characterized cultural administration in the past, and in many cases still do. As Mark O'Neill, Head of Museums and Galleries for Glasgow City Council, concludes in his critique of John Holden's Capturing Cultural Value,

Targets and measurements can be refined, but what can be done about the profound sense amongst... groups of entitlement - entitlement to having their cultural recreations funded without being troubled by the values of a wider society based on democracy, accountability, equity and fairness? ${ }^{9}$

Thus, in addition to more 'abstract' considerations of the pluralization of value in relation to heritage, we are also concerned to focus discussion on the practical and grounded applications, contexts and outcomes of heritage. This is not least because we believe that one of the key issues for contemporary heritage management is how to ensure that it is democratic while at the same time ensuring that the heritage profession does not become a 'Government poodle'?

In introducing this book we would like to take the opportunity to examine more closely some of the coordinates we have sketched out here. What are some of the key historical and cultural constellations for contemporary typologies of value? How has the post-modern pluralization of value been instrumentalized in heritage management?

the UK', Planning Practice and Research, 18, 2-3 (2003): 219-229; C. West and C. Smith, "We are not a Government poodle": Museums and social inclusion under New Labour', International Journal of Cultural Policy, 11, 3 (2005): 275-288.

8 E. Belfiore, 'Art as a means of alleviating social exclusion: Does it really work? A critique of instrumental cultural policies and social impact studies in the UK', International Journal of Cultural Policy, 8, 1 (2002): 91-106; J. Holden, Capturing Cultural Value: How Culture has Become a Tool of Government Policy, (Demos: London, 2004); S. Selwood, 'Measuring Culture', Spiked Culture, http://www.spiked-online.com/Printable/ 00000006DBAF.htm, (2002), accessed 01/09/2003.

9 M. O'Neill, 'Commentaries: John Holden's Capturing Cultural Value: How Culture has Become a Tool of Government Policy', Cultural Trends, 14(1), 53 (2005): 124.

10 C. West and C. Smith, "We are not a Government poodle": Museums and social inclusion under New Labour', op. cit. 
Some of the fundamental premises of the debates explored in this book - the cultural and historical specificity of heritage, the pluralization of value - can be briefly illustrated through examination of the case of perhaps the most iconic British monument of all, Stonehenge. As writers as diverse as the archaeologist Barbara Bender, ${ }^{11}$ the architectural theorist Andrew Ballantyne ${ }^{12}$ and the historian Andy Worthington ${ }^{13}$ have attested the monument has a long history of being interpreted in multiple and conflicting ways; interpretations that are often linked to contemporary purposes and needs. For example, Bender describes how medieval religious attitudes shifted, hardening to become antagonistic to these pre-Christian relics. Subsequently, in the seventeenth and eighteenth centuries, the (now) wellknown works of Inigo Jones, John Aubrey and William Stukeley influenced by contemporary discourses of nationalism and their own cultural pre-dispositions, interpreted Stonehenge as variously a Roman and Druidic monument. As Jacquetta Hawkes wrote in 1967, 'Every age has the Stonehenge it deserves - or desires'. ${ }^{14}$ The site remains enigmatic; a Foucaldian 'heterotopia', a place that is different from itself, as 'people immersed in different cultures come and visit the place they continue to occupy and experience different spaces - Druid space, Merlin space etc.' ${ }^{15}$ These different interpretations of Stonehenge fit within a wider ideological and political discourse about whose values should prevail, with competing and conflicting positions. This was most dramatically evident in the 1980s when a right-wing government (in conjunction with heritage agencies) deployed the sorts of repressive techniques concurrently used in the Miners' Strike, against the heterogeneous, if typically non-conformist, free-festival goers at the socalled Battle of the Beanfield in 1985. State will prevailed and although attitudes have subsequently softened with, for example, limited admission of druids to Stonehenge on the summer solstice, Stonehenge remains a highly controlled and commodified environment. Nevertheless, even within the various agencies responsible for the management of Stonehenge conflicts of value are evident proposals for putting a section of the A303 adjacent to Stonehenge underground and for new visitor facilities have been phenomenally contentious and disputed for over a decade and were dramatically abandoned in late 2007. There is general consensus that the existing visitor facilities are inadequate and poorly sited and that the nearby roads, the A303 long-distance trunk-road and the more local A344 are hugely intrusive. However, it has proved impossible to generate consensus on how to resolve this, with disagreements over siting and how the wider landscape is

11 B. Bender, Stonehenge: Making Space, (Oxford: Berg, 1998).

12 A. Ballantyne, 'Misprisions of Stonehenge' in Architecture as Experience: Radical Change in Spatial Practice edited by D. Arnold and A. Ballantyne, 11-35, (London: Routledge: 2004).

13 A. Worthington, Stonehenge: Celebration and Subversion, (Loughborough: Alternative Albion, 2004).

14 Cited in B. Bender, Stonehenge: Making Space, 114, op. cit.

15 A. Ballantyne, 'Misprisions of Stonehenge', 28, op. cit. 
understood, issues over how much financial resource the Government will devote to improvements and wider complications, such as the large Ministry of Defence operation in the area. Though major road proposals have been abandoned there remains a commitment to improving visitor facilities by the time of the London Olympics in 2012, with a consultation exercise over the form this might take being undertaken in summer 2008.

Stonehenge's enigmatic nature has made it particularly prone, and suitable, to multiple interpretations. We don't really know why it was constructed and we know very little about the people who constructed it other than they inhabited part of the same island space that is today Britain. This opens up possibilities. It could be seen as having a universality;

being in the presence of stones that date from before the advent of nation states or any current civilization, it is possible to entertains ideas of generalized kinship and connectedness with the most fundamental aspects of humanity and of the heavens. ${ }^{16}$

It could be regarded as the ultimate monument of a pluralism that unites rather than divides. As no-one on this island has any real cultural link to the makers of Stonehenge, other than propinquity in space, it could be regarded as having as much relevance to recent immigrants as to those whose ancestors were immigrants in previous millennia; Stonehenge becomes a monument about being here. However, even if this was feasible and desirable it is in turn loaded with cultural assumption, such as, the assumption that all cultures root with the occupation of land. As we consider below, implicit in the notion of 'historic environment' is the idea of place. In other words heritage is perceived as being sedentary, rather than mobile and portable. It is connected to objects that are connected umbilically to a geographical location, rather than by, say the objects carried by nomads or the oral history and traditions treasured by migrants. This concept of heritage was formalized as part of the development of modern conservation practice.

\section{Classifying Value}

The practice of seeking to understand, protect and value heritage has a pre-modern ancestry as we have briefly alluded to above with the example of Stonehenge. However, heritage as we understand it today, in the West at least, is a fundamentally modern practice.

Modernity in this context refers to the broad movement rooted in the Enlightenment period of eighteenth-century Europe that was essentially secular and progressive, in the sense of seeking to break with history and tradition. It is this characteristic of modernity that is most obviously in potential conflict with the

16 A. Ballantyne, 'Misprisions of Stonehenge', 25, op. cit. 
process of heritage, although at the same time providing the stimulus for thought and action. For example, while facilitating the industrial revolution, the Enlightenment also contributed to other processes, including the development of a modern historical consciousness and the nation-state. The new relationships with culture and religion, with nature and environment, generated new conceptions of time. History came to be interpreted as a collective social experience which recognized that different cultures and places had different natures. Historicity, the belief that each period in history has its own beliefs and values, led to a consideration of works of art and of historic buildings as unique, and so worthy of conservation as an expression of a particular culture and a reflection of national identity. ${ }^{17}$ Furthermore, though the origins of the nation-state lie earlier, the concept crystallized in this period, aided by such traumatic events as the French Revolution. A more strongly defined nationalism, based around the territorial unit of the nation-state, demanded both a process of building identity and a common national heritage..$^{18}$ Co-existing with open, dynamic modernity with its push for newness and change is 'traditionalism', which seeks to "harness change and re-cement identity by appealing to the authority of traditions ${ }^{\prime}{ }^{19}$ In the nineteenth century the painful process of primary industrialization was accompanied by an idealization of imagined pasts. David Brett links this to the nineteenth-century concern with 'national character' as part of the process of nation-building. ${ }^{20}$ The distant past was invoked and traditions invented, such as royal pageants, as part of this construction of national heritages. In the context of Victorian England, Charles Dellheim showed how traditions were mobilized flexibly and selectively to support divergent points of view and how heritage was used to reinforce both local and national identity. ${ }^{21}$ Thus various European countries developed legal frameworks and heritage bureaucracies to protect national heritage. At the same time there was a developing view that cultural heritage might have a universal value to mankind.

Thus established processes of heritage are usually inherently 'modern' for two reasons. First, they are a reaction to the threat caused by progressive modernity and the change (whether aesthetic or social) that this implies. The impetus towards conservation and conscious selection and retention of buildings expands with each move to demolish or alter these buildings. It is bound into a complex dialectic with change, and used to affirm the continuity and stability necessary for nationhood. Second, heritage professionals are people of the modern age. Their concepts of history and cultural value and their methods of pursuing their goals are as intrinsically modern as those of the promoters of change. For example, from an

17 J. Jokilehto, A History of Architectural Conservation, (Oxford: Butterworth Heinemann, 1999).

18 B. Graham, G.J. Ashworth, et al., A Geography of Heritage, (London: Arnold, 2000).

19 M. Glendinning, 'A cult of the modern age', Context, 68 (2000): 13.

20 D. Brett, The Construction of Heritage, (Cork: Cork University Press, 1996).

21 C. Dellheim, The Face of the Past: The Preservation of the Medieval Inheritance in Victorian England, (Cambridge: Cambridge University Press, 1982). 
early period they have relied on ideas of selection and classification, eventually expressed in state-defined and controlled lists, and on principles of conservation, which though morally based, can be rationally applied by a skilled elite.

One manifestation of this is the development of classifications and typologies of heritage value. A key historical landmark in this respect is generally taken to be the typology of heritage values produced in 1903 by Alois Riegl, at the time the Austrian state-appointed 'General Conservator', who sought a more refined understanding of the motives which lay behind the process of conservation. ${ }^{22}$ In summary, Riegl divided heritage values into two broad categories. The first was memorial values, such as age value, historical value and intended memorial value and the second present-day values, such as use value, art value, newness value, and relative art value.

Many subsequent typologies have been produced, and whilst there is some acknowledgement of the reductionist problems they can cause, ${ }^{23}$ typologies lie perhaps even more than ever at the heart of the conservation process. Modern conservation practice seeks to determine different strands of value, which generally are labelled under a broad umbrella of cultural significance. These are then mobilized into a process of 'value-led management'. ${ }^{24}$ It is worth briefly noting here that as typologies have evolved we can see an ever-broadening in terms of their scope, most recently embracing, for example, 'intangible values' which have traditionally lain outside Western concepts of heritage value. At the same time, whilst there has been an increasing awareness of the position that heritage values are a social construction of time and place, there has been a stubborn clinging to ideas of 'intrinsic value' and a wish to separate them from the more obviously instrumental performative roles of heritage.

\section{Dealing With Pluralism}

The development of ideas of cultural value and the contingent and variable nature of heritage have very gradually begun to permeate heritage management practice. At least some opening up of ideas of how we value heritage and whose values should inform this process has been evident. A key document in this regard, for its influence far beyond its initial national concerns if for nothing else, has been the Australian Burra Charter. ${ }^{25}$

22 J. Jokilehto, A History of Architectural Conservation, op. cit.

23 E. Avrami, et al., Values and Heritage Conservation, (Los Angeles: The Getty Conservation Institute, 2000).

24 D. Worthing and S. Bond, Managing Built Heritage: The Role of Cultural Significance, (Oxford: Blackwell, 2008).

25 Australia ICOMOS, The Burra Charter: The Australia ICOMOS Charter for Places of Cultural Significance, (Victoria: Australia ICOMOS, 1999), http://www.icomos. org/australia/burra.html. 
The Burra Charter is a document specifically drawn up to inform the conservation of heritage in Australia. First adopted in 1979 and subsequently revised on three occasions (most recently in 1999), its popularity in the UK has principally derived from its recommendations on codifying systematic conservation process; essentially following a sequence of research and analysis before intervention and ensuring the proper documentation of interventions. A parallel manifestation of this Australian importation has been the wide-scale adoption of conservation plans as a means of understanding historic sites and informing decision-making. Within this there are some critical concepts useful for an intelligent approach to managing historic assets. Of particular value is the emphasis placed upon defining significance; what it is that makes a historic site important, before deciding what can be done with it. However, less commented upon is another crucial facet of The Burra Charter that is of interest here; the question of how conservation knowledge is defined.

The starting premise of The Burra Charter is that place is important. To understand the cultural significance of place involves an understanding of familiar elements such as the fabric and its setting and use. But this significance also stems from people's memory and association with place. Thus, judging significance is not just an architectural or archaeological appraisal of fabric, but is also reliant upon incorporating people's experience. How place is valued in conservation terms should not, therefore, be entirely through conventional expert values; although how much this occurs in actual practice, despite reference to the Charter, is questioned by Gibson discussing the Australian state of Queensland in this volume.

In the development of a specifically British discourse on conservation, English Heritage's statement, Sustaining the Historic Environment, was a significant document in opening perspectives on heritage issues to include nonexpert opinion. ${ }^{26}$ The document recognized the potential gap between the sort of historic environment that has been historically validated by conservation values and the types of everyday environments, which people may value and which may underpin local distinctiveness and identity. Stemming from this, Sustaining the Historic Environment identified the importance of recognizing non-expert values and placed an importance on securing wider public participation in conservation debates.

A recent international statement on historic environment value and conservation process has come from the Council of Europe with its Framework Convention on the Value of Cultural Heritage for Society (or Faro Convention). ${ }^{27}$ The Convention seeks to 'square the circle' by combining universalistic notions of heritage with the idea that heritage also needs to be considered pluralistically. The universalistic claim of cultural heritage is considered at a conceptual level and linked to the

26 English Heritage, Sustaining the Historic Environment: New Perspectives on the Future, (London: English Heritage, 1997).

27 Council of Europe, Council of Europe Framework Convention on the Value of Cultural Heritage for Society, (Faro: Council of Europe, 2005). 
concept of rights; that is, people have rights over their cultural heritage. The accompanying commentary claims this to be an innovation of the Convention. ${ }^{28}$ It refers to the 1948 United Nations Universal Declaration of Human Rights, 'Recognizing that every person has a right to engage with the cultural heritage of their choice, while respecting the rights and freedoms of others...'. ${ }^{29}$ Emphasis is placed upon pluralist democratic engagement. Thus Article 12a commits signatories to encouraging everyone to participate in:

- The process of identification, study, interpretation, protection, conservation and presentation of the cultural heritage;

- Public reflection and debate on the opportunities and challenges which the cultural heritage represents. ${ }^{30}$

Cultural heritage is seen as intrinsic to sustainable development, cultural diversity in the face of the threat of homogenizing globalization and a resource around which to construct dialogue, democratic debate and openness between cultures. On this last point the Convention is 'Convinced of the soundness of the principle of heritage policies and educational initiatives which treat all cultural heritages equitably and so promote dialogue among culture and religion'. ${ }^{31}$ The Convention also acknowledges the economic role of heritage and 'without excluding the exceptional, particularly embraces the commonplace heritage of all people'. ${ }^{32}$

Thus, both internationally and in the UK we can see a process whereby heritage management practice has sought to democratize; to embrace more pluralistic definitions of heritage and more inclusive processes of heritage management. However, the shift to a more open and inclusive process of management is not straightforward. For instance, Emma Waterton, Laurajane Smith and Gary Campbell have identified contradictions within The Burra Charter. ${ }^{33}$ Their analysis sees no resolution between its rather vague call for democratization and the continued significance placed upon traditional notions of authority and expertise. Conservation experts continue to reserve to themselves judgements over what has been historically the primary focus of conservation activity, the physical fabric.

However, if the heritage sector were to fully open up considerations of value and significance this would pose some very serious questions for heritage practice. To

28 Council of Europe, Council of Europe Framework Convention on the Value of Cultural Heritage for Society: Explanatory Report, (Faro: Council of Europe, 2005).

29 Council of Europe, Explanatory Report, Preamble, op. cit.

30 Council of Europe, Framework Convention on the Value of Cultural Heritage for Society, Article 12a, op. cit.

31 Council of Europe, Framework Convention on the Value of Cultural Heritage for Society, Preamble, op. cit.

32 Council of Europe, Explanatory Report, 4, op. cit.

33 E. Waterton, L. Smith and G. Campbell, 'The utility of discourse analysis to heritage studies: The Burra Charter and social inclusion', International Journal of Heritage Studies, 12, 4 (2006): 339-355. 
take a fully post-modern approach would potentially plunge heritage management into a relativistic morass, where all values are individual rather than collective and any possibility of a shared narrative illusory. A philosophically less extreme issue for the heritage sector could be that a more pluralistic approach to heritage opens up different sorts of consensus, which are in conflict with the dominant values in the sector. For instance, in the context of the parallel activity of countryside conservation, Philip Goodwin has argued that the extension of participation in countryside conservation 'may be bringing about a retreat from the national vision of traditional conservation and a fragmentation of conservation ideas' ${ }^{34}$ Again, this takes heritage agencies into potentially deeply uncomfortable territory.

Waterton and colleagues suggest that whilst The Burra Charter encourages wider participation in defining meaning in the historic environment, it does not relinquish control from the experts over defining cultural significance, the key measure guiding management decisions. Extending this argument, how much are the efforts of the heritage sector on contemporary agendas of pluralism actually about retaining control in the face of political hostility? Is the sector prepared to relinquish at least a measure of control, or is the rhetoric of pluralism used as lipservice to sustain control in the face of broader political agendas? Should the various pronouncements and heritage statements discussed above be seen as part of an evolving family of documents that seek to rationalize and justify orthodox versions of the importance of heritage protection, part of Laurajane Smith's 'Authorized Heritage Discourse'? ${ }^{35}$

Whilst there are clear grounds for such a critique we would wish to put forward four qualifications on this. First, orthodox heritage practice has reformed and evolved. Whilst it is evident that, not surprisingly, the heritage sector wishes to sustain its own authority and power it is our contention that there has been some genuine efforts at a wider democratic engagement, however limited, and a degree of reflexive institutional reform, and that there is the potential for this reform to continue and evolve. We believe that constructive engagement with this reform potential requires attendance to the practical conditions for heritage's management as well as critical analysis of the discourses which inform it. Second, as John Pendlebury, Tim Townshend and Rose Gilroy argue in this volume in relation to Byker, the 'Authorized Heritage Discourse', in implementation at least, should not be seen exclusively as inflexible and monolithic. ${ }^{36}$ The accepted narrative of place can develop from dialogue including powerful and articulate local voices, rather than being simply an external elite imposition. The challenge for heritage management is how to enable these dialogues and then to reflect them in practice. Third, different spheres of heritage activity have different potentials and

34 P. Goodwin, 'The end of consensus? The impact of participatory initiatives on conceptions of conservation and the countryside in the United Kingdom', Environment and Planning D: Society and Space, 17 (1999): 383.

35 L. Smith, Uses of Heritage, (Oxford: Routledge, 2006).

36 Pendlebury et al., this volume. 
limitations. For example, the Heritage Lottery Fund has shifted priority from large capital projects of physical conservation to a greater emphasis upon community benefit and small community-led projects with no physical conservation element. Such a shift would be much harder to achieve in the domain of conservationplanning, with its extensive collections of statutorily protected assets and where the alternative to protection by cultural elites might in practice lead to local development nexuses, generally powerful in local governance, moving in, with consequent traducing or even erasure of the historic environment. Again in the conservation-planning arena, devolving power further to local communities may just result in empowering a NIMBYism that is in reality primarily concerned with other issues, such as sustaining property values. Fourth, many critiques of current heritage practice seek a more devolved, more inclusive, community-led process of heritage identification, protection and management. In addition to the problems we have already identified with this aspiration, and see Pendlebury et al and Gibson in this volume for further consideration of these issues, it also contains an implicit assumption that people want to be engaged in this process. The work of Nicolas Shore challenges this. ${ }^{37}$ His interviews with Asian residents in Gloucester found many people had a high degree of respect for traditional narratives of heritage (such as the Cathedral and Docks in Gloucester) but little wish to engage. Indeed, Shore found that whatever the attitudes respondents held towards authorized heritage there was no sense of exclusionary barriers or the need for reformist inclusionary policies.

\section{Themes and Structure of this Book}

While all the chapters in this book explore typologies and constructions of value the chapters in Part I, 'Values and Heritage Stewardship', are particularly focused on this through their identification and discussion of 'crises' or, at the least, endemic failures in the stewardship of material culture. In his contribution David Lowenthal identifies a 'crisis' facing contemporary museums, which, he argues, are 'beleaguered because fast-changing views of their proper functions lumber them with multiple and ever more incompatible missions' ${ }^{38}$ Lowenthal argues that these challenges are not particular to museums but that the entire heritage sector 'is in a perpetual state of emergency' as it seeks to be at one and the same time responsive to the desires of the Government and at the same time retain its own internal authority and meaning. ${ }^{39}$ For Lowenthal museums must be careful about the extent to which they attach their heritage

37 N. Shore, Whose Heritage? The Construction of Cultural Built Heritage in a Pluralist, Multicultural England. (Ph.d. Thesis, School of Architecture, Planning and Landscape, Newcastle University: 2007).

38 Lowenthal, this volume, 19.

39 Ibid., 19. 
stewardship to individual or community identity as to do so risks allowing heritage to be used for 'national or tribalist aims' ${ }^{40}$ Rather, heritage stewardship must seek to retain the 'detached distancing' that enables its institutions to function 'as reliable vehicles of public illumination'. ${ }^{41}$ According to Laurajane Smith this 'detached distancing' is part of a structure she has termed the 'Authorized Heritage Discourse' (AHD). Smith has discussed the dimensions of the AHD at length elsewhere, ${ }^{42}$ in this volume she is concerned to document a particular instance of the social affect of the AHD. Smith argues that heritage is not the bearer of particular intrinsic values but is in fact a process which functions to transmit particular values, including social values, that 'society or sections of a society wish to preserve and "pass' on". ${ }^{33}$ Smith demonstrates the social affect of this 'heritage as process' through the discussion of research undertaken with visitors to English country houses. She argues that the function of the English country house as 'heritage' is to act as a vehicle for the assertion of class hierarchy. Peter Howard is concerned with another kind of elitism, the exclusive control of heritage by experts. He argues that the construction of heritage as a concept, its designation and its contemporary management is dictated by experts - not only heritage managers but also historians, geologists and others. However, Howard does not advocate a simple replacement of 'expertise' with 'the people' but calls for experts to 'get off our seat comfortably behind Caesar, and get down into the arena and dispute with others as to the future heritage' ${ }^{44}$ On this reading different expert disciplines become communities whose interests can be debated on an even plane with other 'non-expert' communities.

'The historic environment' has for some time been a key term in heritage policy in England and is currently the preferred English Heritage terminology for referring to heritage, such as buildings and places. ${ }^{45}$ In Australia too the phrase is key, for instance, the journal of Australian ICOMOS is titled Historic Environment. However, as Peter Howard has discussed in his contribution to this book, UNESCO and the Council of Europe have preferred the term 'cultural landscape' as in, for instance, the European Landscape Convention ${ }^{46}$ In one of the formative statements of the English 'historic environment', Power of Place, the starting point is the results of a MORI survey which purported to demonstrate the 'power of place'. ${ }^{47}$ 'People care' about 'the historic environment' the document concludes in its first

40 Ibid., 29.

41 Ibid., 30.

42 L. Smith, Uses of Heritage, op. cit.

43 Smith, this volume, 33.

44 Howard, this volume, 61.

45 The term 'historic environment' first came to be used as a key phrase in English heritage policy in 1994 with the publication of Planning Policy Guidance 15: Planning and the Historic Environment (PPG15).

46 Council of Europe, European Landscape Convention, 2000, http://conventions. coe.int/Treaty/en/Treaties/Html/176.htm.

47 English Heritage, Power of Place: The Future of the Historic Environment, (London: English Heritage, 2000). 
few pages. ${ }^{48}$ From this opening position where the importance of the 'historic environment' to 'the people' is established, the document goes on to state that 'the historic environment is what generations of people have made of the places in which they lived' ${ }^{49}$ Thus, Power of Place describes a 'historic environment' in which change takes place; nevertheless, the articulation of 'historic environment' here and as it has developed since then, is of a 'historic environment' which is primarily valued for the traces of the past embodied within it. If this understanding of the past is a little more plural than perhaps twenty years ago, the nomenclature of 'historic environment' still militates against the possibility of more active and contemporary engagements with landscapes which might produce new versions of the past or by new versions of the past as represented in markers of the present. ${ }^{50}$ The 'historic environment' therefore is constitutively limited. It is for this reason that we have titled Part II 'Cultural Landscapes'.

The chapters in Part II discuss a variety of cultural landscapes and construct their object - 'landscape' or 'environment' - in different ways. Lisanne Gibson's chapter on the cultural landscape of the Australian state of Queensland discusses the designation and management of monuments, memorials and public art. She argues that, despite heritage programmes which include a focus on cultural and social value, many communities histories and experiences are not represented by the outdoor cultural objects in Queensland which are managed as heritage. Gibson's point in this chapter is to underscore the social and political affects of heritage. John Schofield is also concerned to investigate the ways in which people engage with cultural heritage and landscape. Particularly, he is interested in exploring the material culture and landscapes which evoke 'the more personal meanings and values... than state-led mechanisms for heritage management currently allow' ${ }^{51}$ Like Gibson he identifies that these objects and places are often not designated as 'special' and afforded statutory protection. Schofield is not necessarily advocating statutory protection as the only or best tool for heritage's management but is interested in exploring 'why these intimate engagements matter and how they can be made more widely available to those who want to share in them'. ${ }^{52}$ John Walton and Jason Wood in making the case for the World Heritage listing of Blackpool, 'the world's first working-class seaside resort', ${ }^{53}$ are also interested in heritage which is more 'everyday'. Walton and Wood discuss the cultural landscape of Blackpool as 'heritage of the recent past' and consider the modalities which allow such a reading. The designation of Blackpool as a World Heritage Site is also considered in terms of its instrumental benefits; specifically

48 Ibid., 4.

49 Ibid.

50 See also Howard's discussion of the problems with the 'historic environment' terminology in this volume.

51 Schofield, this volume, 93.

52 Ibid., 94.

53 Walton and Wood, this volume, 115. 
Walton and Wood argue that there would be regeneration effects, such as, a boost to the economy from increased tourism, from such a listing. Tracey Avery is also concerned with the practical dimensions of preservation in her discussion of the statutory protection of 'street art' in the laneways of the Australian city of Melbourne. In her discussion of the National Trust's (Victoria) involvement in debates about the protection of what some members of the community term 'graffiti' and others term 'art', Avery is concerned with both the historic and social values of this kind of 'street art' but also with the conceptual and practical problems for heritage management presented by such material culture.

The third section focuses on 'The Heritage of Housing'. Peter Borsay gives a long historical perspective over how something that might now seem the bedrock of a particular type of Englishness, the Georgian house, has been perceived in a variety of historically contingent ways. The status it now enjoys as a heritage icon has evolved and been actively 'made'. Both subsequent chapters in this section focus on the valorization of twentieth-century social housing as heritage. Unlike the value now attributed to the Georgian house, the protection and conservation of large-scale welfare state housing is often controversial, as it is a form of development often held in low regard by many. Inevitable debates arise over whether identifying such housing as 'special' is the imposition of an avant-garde cultural elite on residents and on the public purse. This is the primary focus of the chapter by John Pendlebury, Tim Townshend and Rose Gilroy that considers the listing of the Byker Estate in Newcastle upon Tyne and how it relates to local conceptions of place and how it might influence the future of the estate. Whilst also examining social housing, Peter Malpass delves into perhaps more fundamental issues about housing as heritage; houses have a very particular cultural construction around the idea of 'home' and the way this relates to personal identity These different ways of constructing heritage - as part of a wider architectural historical narrative or something more personal - are at the heart of Malpass's chapter, where he makes a separation between 'Heritage' and 'heritage'. He examines this distinction using the examples of the Sea Mills Estate in Bristol and the Byker Estate in Newcastle upon Tyne.

Valuing Historic Environments considers a diverse array of environments and landscapes, some of which have been officially designated 'heritage', some have not. All, however, are valued in various ways by different groups and individuals. Can 'heritage' with all its conceptual and practical limitations encompass all of these different engagements with material and indeed intangible culture? Probably not. But the constant critical engagement with the discourses which inform 'heritage', the practical considerations which constrain it and above all the cultural, social and political affects of its management (or not) is not a sign of the failure of the 'heritage' concept. On the contrary, the vigour of the debate is a sign that in addition to elitism there is also a democratic liberalism which is a central, although perhaps paradoxical, element of the heritage discourse. 


\section{Bibliography}

Australia ICOMOS The Burra Charter: The Australia ICOMOS Charter for Places of Cultural Significance. Victoria: Australia ICOMOS, 1999. http:// www.icomos.org/australia/burra.html.

Avrami, E. et al. Values and Heritage Conservation. Los Angeles: The Getty Conservation Institute, 2000.

Ballantyne, A. 'Misprisions of Stonehenge' in Architecture as Experience: Radical Change in Spatial Practice edited by D. Arnold and A. Ballantyne, 11-35, London: Routledge, 2004.

Belfiore, E. 'Art as a means of alleviating social exclusion: Does it really work? A critique of instrumental cultural policies and social impact studies in the UK', International Journal of Cultural Policy, 8, 1 (2002): 91-106.

Bender, B. Stonehenge: Making Space. Oxford: Berg, 1998.

Bennett, T. and Savage, M. 'Introduction: Cultural capital and cultural policy', Cultural Trends 13, 2 (2004): 7-14.

Bennett, T. and Silva, E.B., 'Cultural capital and inequality: Policy issues and contexts', Cultural Trends, 15, 2/3 (2006): 87-106.

Bourdieu, P. Distinction: A Social Critique of the Judgement of Taste. Oxford: Routledge, 1984.

Brett, D. The Construction of Heritage. Cork: Cork University Press, 1996.

Council of Europe Council of Europe Framework Convention on the Value of Cultural Heritage for Society. Faro: Council of Europe, 2005.

Council of Europe Council of Europe Framework Convention on the Value of Cultural Heritage for Society: Explanatory Report. Faro: Council of Europe, 2005.

Council of Europe European Landscape Convention. http://conventions.coe.int/ Treaty/en/Treaties/Html/176.htm, 2000.

Davis, P. Ecomuseums: A Sense of Place. Leicester: Leicester University Press, 1999.

De La Torre, M. Assessing the Values of Cultural Heritage. Los Angeles: The Getty Conservation Institute, 2002.

Dellheim, C. The Face of the Past: The Preservation of the Medieval Inheritance in Victorian England. Cambridge: Cambridge University Press, 1982.

English Heritage Power of Place: The Future of the Historic Environment. London: English Heritage, 2000.

English Heritage Sustaining the Historic Environment: New Perspectives on the Future. London: English Heritage, 1997.

Gibson, L. 'In defence of instrumentality', Cultural Trends, 17, 4 (2008): 247257.

Gibson, L. The Uses of Art: Constructing Australian Identities. Brisbane: University of Queensland Press, 2001.

Gibson, L. and Besley, J. Monumental Queensland: Signposts on a Cultural Landscape, Brisbane: University of Queensland Press, 2004. 
Glendinning, M. 'A cult of the modern age', Context, 68 (2000): 13-15.

Goodwin, P. 'The end of consensus? The impact of participatory initiatives on conceptions of conservation and the countryside in the United Kingdom', Environment and Planning D: Society and Space, 17 (1999): 383-401.

Graham, B. Ashworth, G.J. and Tunbridge, J.E. A Geography of Heritage. London: Arnold, 2000.

Harvey, D. The Condition of Postmodernity. Oxford: Blackwell, 1990.

Healey, P. Collaborative Planning: Shaping Places in Fragmented Societies. Basingstoke: Macmillan, 2006.

Holden, J. Capturing Cultural Value: How Culture has Become a Tool of Government Policy. Demos: London, 2004.

Jencks, C. What is Post-Modernism? Chichester: Academy Editions, 1996.

Jokilehto, J. A History of Architectural Conservation. Oxford: Butterworth Heinemann, 1999.

Newman, A., McLean, F. and Urquhart, G. 'Museums and the active citizen: tackling the problems of social exclusion', Citizenship Studies, 9, 1 (2005): $41-57$.

O’Neill, M. 'Commentaries: John Holden's Capturing Cultural Value: How Culture has Become a Tool of Government Policy', Cultural Trends, 14(1), 53 (2005): 113-128.

Pendlebury, J. Conservation and the Age of Consensus. London: Routledge, 2009.

Pendlebury, J., et al. 'The conservation of english cultural built heritage: A force for social inclusion?', International Journal for Heritage Studies, 10, 1 (2004): $11-32$.

Selwood, S. 'Measuring culture', Spiked Culture. http://www.spiked-online.com/ Printable/00000006DBAF.htm, 2002, accessed 01/09/2003.

Shore, N. Whose Heritage? The Construction of Cultural Built Heritage in a Pluralist, Multicultural England. Ph.D. Thesis, School of Architecture, Planning and Landscape, Newcastle University, 2007.

Smith, L. Uses of Heritage. Oxford: Routledge, 2006.

Strange, I. and Whitney, D. 'The changing roles and purposes of heritage conservation in the UK', Planning Practice and Research, 18, 2-3 (2003): 219-229.

Waterton, E., Smith, L., and Campbell, G. 'The utility of discourse analysis to heritage studies: The Burra Charter and social inclusion', International Journal of Heritage Studies, 12, 4 (2006): 339-355.

West, C. and Smith, C. "'We are not a Government poodle": Museums and social inclusion under New Labour', International Journal of Cultural Policy, 11, 3 (2005): 275-288.

Worthing, D. and S. Bond, Managing Built Heritage: The Role of Cultural Significance. Oxford: Blackwell, 2008.

Worthington, A. Stonehenge: Celebration and Subversion. Loughborough: Alternative Albion, 2004. 